\title{
Effects of dietary fat and carbohydrate exchange on human energy metabolism
}

Citation for published version (APA):

van Verboeket, W. P. H. G., \& Westerterp, K. R. (1996). Effects of dietary fat and carbohydrate exchange on human energy metabolism. Appetite, 26(3), 287-300. https://doi.org/10.1006/appe.1996.0022

Document status and date:

Published: 01/01/1996

DOI:

10.1006/appe.1996.0022

Document Version:

Publisher's PDF, also known as Version of record

Document license:

Taverne

Please check the document version of this publication:

- A submitted manuscript is the version of the article upon submission and before peer-review. There can be important differences between the submitted version and the official published version of record.

People interested in the research are advised to contact the author for the final version of the publication, or visit the DOI to the publisher's website.

- The final author version and the galley proof are versions of the publication after peer review.

- The final published version features the final layout of the paper including the volume, issue and page numbers.

Link to publication

\footnotetext{
General rights rights.

- You may freely distribute the URL identifying the publication in the public portal. please follow below link for the End User Agreement:

www.umlib.nl/taverne-license

Take down policy

If you believe that this document breaches copyright please contact us at:

repository@maastrichtuniversity.nl

providing details and we will investigate your claim.
}

Copyright and moral rights for the publications made accessible in the public portal are retained by the authors and/or other copyright owners and it is a condition of accessing publications that users recognise and abide by the legal requirements associated with these

- Users may download and print one copy of any publication from the public portal for the purpose of private study or research.

- You may not further distribute the material or use it for any profit-making activity or commercial gain

If the publication is distributed under the terms of Article $25 \mathrm{fa}$ of the Dutch Copyright Act, indicated by the "Taverne" license above, 


\title{
Effects of Dietary Fat and Carbohydrate Exchange on Human Energy Metabolism
}

\author{
W. P. H. G. VERBOEKET-VAN DE VENNE and K. R. WESTERTERP \\ University of Limburg, Maastricht, The Netherlands
}

\begin{abstract}
Short-term effects of low-fat ( $10 \%$ fat energy), mixed ( $30 \%$ fat energy), and highfat $(50 \%$ fat energy) diets on 24-h energy expenditure, and on its components sleeping metabolic rate, diet induced thermogenesis and energy expenditure for physical activity were studied for 3 days using a respiration chamber in twelve normal-weight female volunteers classified as restrained or unrestrained eaters. There were no significant differences in any of the four measures between the restrained and unrestrained eating subjects on any of the diets. Within the group of restrained eaters, 24-h energy expenditure was significantly decreased during consumption of the mixed diet $(8.21 \pm 0.21 \mathrm{MJ} / \mathrm{d} ; \mathrm{p}<0.01)$ and tended to be decreased on the high-fat diet $(8.22 \pm 0.25 \mathrm{M} \mathrm{J} / \mathrm{d} ; \mathrm{p}=0.055)$, relative to the lowfat diet $(8.58 \pm 0.21 \mathrm{M} \mathrm{J} / \mathrm{d})$. D iet composition had no effect on 24-h energy expenditure in the women with unrestrained eating. The results suggest that a lowfat diet would be beneficial in the treatment of obesity, especially if subjects have a restrained type of eating behaviour.

(c) 1996 A cademic Press Limited
\end{abstract}

\section{INTRODUCTION}

$\mathrm{H}$ igh-fat diets have been associated with obesity in humans (D reon et al., 1988; R omieu et al., 1988; Tremblay et al., 1989). Because obesity results from a positive energy balance, i.e. energy intake exceeding energy expenditure, two possible mechanisms are involved. Firstly, a high-fat diet could result in an increase of energy intake (D uncan et al., 1983; Lissner et al., 1987; Tremblay et al., 1989). The second possibility is that high-fat diets lower energy expenditure, which in turn has been shown to be a risk factor for weight gain (R avussin et al., 1988). Changing the macronutrient ratio of the diet may have consequences for the regulation of energy balance through changes in one or more of the three components of daily energy expenditure: sleeping metabolic rate (SM R), diet induced thermogenesis (DIT) and energy expenditure for physical activity (A CT). A ccording to F latt (1985), dietary fat storage is at a cost of $3 \%$ of ingested energy, whereas the cost of storing dietary carbohydrate as fat requires the expenditure of $23 \%$ of ingested energy. F urthermore, variations in the thermogenic response were reported with respect to the composition of the diet. A lower thermogenic response to fat than to carbohydrate was described for both normal weight and obese subjects (Schwartz et al., 1985) and post-obese

D r M . S. Westerterp-Plantenga's assistance in using the psychometric questionnaires and valuable comments on the paper are gratefully acknowledged.

Correspondence to: D r W.P.H.G. Verboeket-van de Venne, D epartment of H uman Biology, U niversity of Limburg, P.O. Box 616, 6200 M D M aastricht, The N etherlands. 
subjects (L ean \& J ames, 1988). Thus, the contribution of D IT to energy metabolism is expected to be lower on a high-fat diet.

A nother aspect that has to be considered in the processes leading to obesity is the between-subject variation in the response to dietary fat. $\mathrm{N}$ air et al. (1983) found no differences in the magnitude of the thermic response to isoenergetic protein, carbohydrate or fat meals between groups of lean and obese subjects. Other studies, however, support the view that there is a defect in thermogenesis in response to fat in obese subjects (Swaminathan et al., 1981; Zed \& James, 1986). Less is known about the metabolic response to food stimuli of latent obese subjects. By means of the scores of psychometric questionnaires a distinction can be made between subjects with a restrained or unrestrained attitude towards eating. Laessle et al. (1989) and Tuschl et al. (1990) reported less energy consumption and higher preferences for low-energy foods in restrained eating subjects compared with unrestrained eating subjects, despite having a higher body mass index. F urthermore, energy expenditure was lower in restrained eating subjects, reflecting diminished energetic requirements.

In the present study, the short-term effects of dietary fat and carbohydrate exchange on human energy metabolism were investigated. F urthermore, the subjects' attitude towards eating was taken into account, in order to determine metabolic responses to diet composition of subjects being more (restrained eating subjects) or less (unrestrained eating subjects) susceptible to becoming obese.

\section{ETHOD}

Subjects

Twelve healthy women of normal weight were selected for this investigation. Their physical characteristics are presented in Table 1. The procedures to be used in the study were carefully explained to each subject before she gave her consent to participate. The protocol was reviewed and approved by the U niversity of Limburg Ethical Committee.

\section{A ttitude towards eating}

R estrained and unrestrained eating subjects were selected by means of the scores on psychometric questionnaires. Two types of psychometric questionnaires were used: the Herman-Polivy (H-P) restraint scale (Herman \& Polivy, 1980) which is designed to identify dieters and is mainly weight-concerned (Westerterp-Plantenga et al., 1991), and the Three F actor Eating Questionnaire (TFEQ) of Stunkard and $M$ essick (1985) which is designed to measure successful dieting and is mainly foodconcerned (Westerterp-Plantenga et al., 1991). U sing the H-P restraint scale, we can discriminate between being a restrained or unrestrained eater. Considering studies of Westerterp-Plantenga et al. (1990a, 1990b, 1991) the median of the H-P scores in the subject population used at the D epartment of H uman Biology, U niversity of Limburg, M aastricht was 15 . Thus, subjects with a score $>15$ were classified as restrained eaters and subjects with a score $\leq 15$ were classified as unrestrained eaters. The TFEQ of Stunkard and Messick (1985) was used to discriminate between cognitive restraint and unrestraint, concerning the scores on the cognitive restraint factor $F_{1}$. The median of the scores on $F_{1}$ in the population of subjects was 9 
TABLE 1

Physical characteristics of the subjects and order of treatment

\begin{tabular}{|c|c|c|c|c|c|c|c|}
\hline \multirow[t]{2}{*}{ Subject } & \multirow[t]{2}{*}{$\begin{array}{l}\text { A ge } \\
\text { (yr) }\end{array}$} & \multirow[t]{2}{*}{$\begin{array}{l}\text { Weight } \\
\text { (kg) }\end{array}$} & \multirow[t]{2}{*}{$\begin{array}{l}\text { H eight } \\
\text { (m) }\end{array}$} & \multirow[t]{2}{*}{$\begin{array}{c}\text { Percentage } \\
\text { body fat }\end{array}$} & \multicolumn{2}{|c|}{$\begin{array}{l}\text { Questionnaire } \\
\text { scores }\end{array}$} & \multirow[t]{2}{*}{$\begin{array}{l}\text { Order of } \\
\text { treatment }\end{array}$} \\
\hline & & & & & $\mathrm{H}-\mathrm{P}$ & $F_{1}$ & \\
\hline $\begin{array}{l}1 \\
2 \\
3 \\
4 \\
5 \\
6 \\
\text { M ean } \\
\text { SE }\end{array}$ & $\begin{array}{r}20 \\
20 \\
21 \\
21 \\
21 \\
21 \\
21 \\
0\end{array}$ & $\begin{array}{r}65 \cdot 5 \\
71 \cdot 1 \\
64 \cdot 5 \\
67 \cdot 7 \\
59 \cdot 5 \\
67 \cdot 2 \\
65 \cdot 9 \\
1 \cdot 6\end{array}$ & $\begin{array}{l}1.75 \\
1.73 \\
1.71 \\
1.75 \\
1.60 \\
1.73 \\
1.71 \\
0.02\end{array}$ & $\begin{array}{r}19 \cdot 8 \\
21 \cdot 1 \\
26 \cdot 5 \\
21 \cdot 7 \\
22 \cdot 7 \\
28 \cdot 6 \\
23 \cdot 4 \\
1 \cdot 4\end{array}$ & $\begin{array}{r}13 \\
18 \\
17 \\
19 \\
17 \\
17 \\
17 \\
1\end{array}$ & $\begin{array}{r}11 \\
7 \\
11 \\
15 \\
7 \\
6 \\
10 \\
1\end{array}$ & $\begin{array}{l}\text { LF-HF-M } \\
\text { LF-HF-M } \\
\text { LF-HF-M } \\
\text { LF-HF-M } \\
\text { HF-LF-M } \\
\text { HF-LF-M }\end{array}$ \\
\hline $\begin{array}{l}7 \\
8 \\
9 \\
10 \\
11 \\
12 \\
\text { M ean } \\
\text { SE }\end{array}$ & $\begin{array}{r}20 \\
22 \\
19 \\
19 \\
24 \\
20 \\
21 \\
1\end{array}$ & $\begin{array}{r}80 \cdot 1 \\
68 \cdot 4 \\
69 \cdot 7 \\
57 \cdot 7 \\
62 \cdot 6 \\
61 \cdot 9 \\
66 \cdot 7 \\
3 \cdot 2\end{array}$ & $\begin{array}{l}1.71 \\
1.71 \\
1.71 \\
1.70 \\
1.76 \\
1.63 \\
1.70 \\
0.02\end{array}$ & $\begin{array}{r}32 \cdot 0 \\
28.6 \\
28 \cdot 9 \\
22 \cdot 2 \\
21 \cdot 0 \\
28 \cdot 4 \\
26.9 \\
1.8\end{array}$ & $\begin{array}{r}6 \\
12 \\
11 \\
10 \\
7 \\
6 \\
9 \\
1\end{array}$ & $\begin{array}{l}3 \\
1 \\
4 \\
0 \\
0 \\
4 \\
2 \\
1\end{array}$ & $\begin{array}{l}L F-H F-M \\
H F-L F-M \\
H F-L F-M \\
L F-H F-M \\
L F-H F-M \\
H F-L F-M\end{array}$ \\
\hline
\end{tabular}

$\mathrm{H}-\mathrm{P}$ : score on the $\mathrm{H}$ erman-Polivy dietary restraint questionnaire (H erman \& Polivy, 1980). $\mathrm{F}_{1}$ : score on the cognitive restraint factor of the Three F actor Eating Questionnaire (Stunkard \& M essick, 1985).

LF, low-fat diet; $M$, mixed diet; HF, high-fat diet.

(Westerterp-Plantenga et al., 1990a, 1990b, 1991) implying that subjects with an $F_{1}$ score $>9$ were classified as cognitive restraint, and a score $\leq 9$ as unrestraint. Overall, subjects in the present study were classified as restrained eaters when $\mathrm{H}-\mathrm{P}$ score $>15$ or $\mathrm{F}_{1}$ score $>9$; unrestrained eating subjects had an $\mathrm{H}-\mathrm{P}$ score $\leq 15$ and an $\mathrm{F}_{1}$ score $\leq 9$. F rom the six subjects classified as restrained eaters, three subjects were restrained by being weight-concerned (subjects 2,5 and 6 ), one subject by being food-concerned (subject 1), and two subjects by being weight- and food-concerned (subjects 3 and 4).

\section{Experimental design}

Subjects were fed to energy balance consuming a low-fat (LF), a mixed (M) and a high-fat (HF) diet over 3-day intervals. The order of administration of $L F$ and HF diet was randomized; for practical reasons the $M$ diet was always administered last. The interval between two experimental periods was at least 4 days. The first 2 days on each dietary regimen the provided food was consumed at home, followed by the last day of each period while the subjects stayed in a respiration chamber for approximately $36 \mathrm{~h}$. In this chamber oxygen consumption, carbon dioxide production, and hence respiratory quotient $(R Q)$ and energy expenditure $(E E)$, were the main measurements (see below). Energy intake for the maintenance of energy balance was based on the calculated basal metabolic rate (BM R) (Harris \& Benedict, 1919) of the subjects multiplied by 1.76 on days 1 and 2 (Verboeket-van de Venne et al., 
1993); energy intake on day 3 while being in the respiration chamber equalled $1.29 \times$ BM R (Verboeket-van de Venne \& Westerterp, 1991).

\section{Diets}

The diets were taken as four meals daily: a breakfast at $0800 \mathrm{hrs}$ containing $20 \%$ of the daily energy intake, a lunch at $1300 \mathrm{hrs}$ ( $25 \%$ of energy intake), a dinner at $1800 \mathrm{hrs}$ ( $45 \%$ of energy intake), and an evening snack at $2030 \mathrm{hrs} \mathrm{(10 \%} \mathrm{of} \mathrm{energy}$ intake). Between the meals no extra consumptions were allowed, except for coffee and tea (without milk and sugar), mineral water, and tap water. The total energy intake was the same for the three diets. As a percentage of energy content, the LF diet provided $15 \%$ protein, $10 \%$ fat (4\% as saturated fatty acids, $4 \%$ as monounsaturated fatty acids, $2 \%$ as polyunsaturated fatty acids), and $75 \%$ carbohydrate; the $M$ diet provided $15 \%$ protein, $30 \%$ fat (13\% saturated, $12 \%$ monounsaturated, $5 \%$ polyunsaturated fatty acids), and $55 \%$ carbohydrate; and the H F diet provided $15 \%$ protein, $50 \%$ fat $(23 \%$ saturated, $20 \%$ monounsaturated, $7 \%$ polyunsaturated fatty acids), and $35 \%$ energy as carbohydrate (see A ppendix for a description of the diets). Energy content and macronutrient composition of the diets were calculated using the Dutch food composition table (H autvast, 1975).

\section{Determination of 24-h RQ, 24-h EE, SM R, DIT and ACT}

Oxygen consumption and carbon dioxide production were measured on the third day of each dietary regimen using a respiration chamber. The chamber was $14 \mathrm{~m}^{3}$ and furnished with a bed, chair, table, television, radio, telephone, wash-bowl and toilet facilities, and was ventilated with fresh air at a rate of $50 \mathrm{l} / \mathrm{min}$ (Schoffelen et al., 1984). The ventilation rate (I) was measured with a dry gasmeter (Schlumberger, type $G 6$ ). The concentration of oxygen and carbon dioxide was measured using a paramagnetic $\mathrm{O}_{2}$ analyser (Servomex, type OA 184) and an infrared $\mathrm{CO}_{2}$ analyser (Hartmann \& Braun, type URAS 3G ). Air samples were analysed every minute. Each 15-min period contained 12 outgoing samples, one ingoing sample, a span gas sample (certified calibration gas: $0.800 \% \mathrm{CO}_{2}, 18.0 \% \mathrm{O}_{2}$ ) and an $\mathrm{N}_{2}$ sample for zeroing. In this way the system was providing full calibration values every $15 \mathrm{~min}$. The gas samples to be measured were selected by a computer which also stored and processed the data. During daytime subjects were not restricted and their activity was spontaneous: they were allowed to move freely within the chamber, to sit, lie down, study, telephone, listen to the radio and watch television, but no strenuous exercise, gymnastics or sleeping were allowed. Therefore, most activities performed were of a sedentary nature. The physical activity was inconspicuously monitored by means of a radar system (Schutz et al., 1982). The unit continuously emitted a radar signal of constant frequency into the respiration chamber. The signal, which was reflected by the walls of the chamber and objects within it, was detected by a radar transreceiver working on the D oppler principle.

$\mathrm{RQ}$ was calculated as the ratio of $\mathrm{CO}_{2}$ produced to $\mathrm{O}_{2}$ consumed; $\mathrm{EE}$ was calculated according to Weir (1949) from $\mathrm{O}_{2}$ consumption and $\mathrm{CO}_{2}$ production. Twenty-four-hour values were calculated from $0730 \mathrm{hrs}$ to $0730 \mathrm{hrs}$. SM R was determined from $0300 \mathrm{hrs}$ to $0600 \mathrm{hrs}$, when energy expenditure was lowest and radar output was at baselinelevel. Themethod used for determination of D IT was previously described by Schutz et al. (1984) and was based on simultaneous measurements of 
both physical activity and energy expenditure of the subjects. The individual relationship between the physical activity and energy expenditure both averaged over 30 min periods was plotted. Only the intervals after the first meal until bedtime were used, i.e. from $0800 \mathrm{hrs}$ to $2300 \mathrm{hrs}$ ( $=15$ postprandial hours). The intercept of the regression line at zero activity represented the energy expenditure in the inactive state $\left(E_{0 \text { activity }}\right)$ consisting of two components: $S M R$ and DIT. By subtracting SM R from $E_{0 \text { activity }}$ we obtained $D I T$, and corrected it for the relevant time interval. ACT was assessed by 24-h EE minus $E_{0} E_{0 \text { activity. }}$ Thus, the separate components of energy metabolism were obtained by the following equations

$$
\begin{aligned}
& S M R=\text { measured from } 0300 \text { to } 0600 \text { hrs } \\
& D I T=\left(E E_{0 \text { activity }}-S M R\right) \times(\text { postprandial hours/24) } \\
& A C T=24-h E E-E E_{0 \text { activity }}
\end{aligned}
$$

Body weight and body composition

Subjects weighed themselves (without clothing) in the morning of days 1, 3 and 4 upon rising, after voiding and before any food/drink consumption, on a digital balance (Seca delta, model 707) accurate to $0.1 \mathrm{~kg}$.

Whole-body density was determined once by underwater weighing in the fasted state, after the subjects left the respiration chamber. L ung volume was measured simultaneously with the $\mathrm{H}$ e dilution technique using a spirometer (Volugraph 2000, $\mathrm{M}$ ijnhardt, The $\mathrm{N}$ etherlands). Percentage body fat was calculated using the equations of Siri (1956).

\section{A nalysis of data}

The effects of diet composition on 24-h EE, SM R, DIT and ACT of all subjects were analysed by repeated measures analysis of variance (A N OVA) and Scheffé F tests. Differences between the groups of restrained and unrestrained eating subjects on the three diets were tested using two-factor repeated measures ANOVA, with "attitude towards eating" as the grouping factor and "diet composition" as the repeated measures factor. Correlation between physical activity and energy expenditure was analysed using the Pearson correlation coefficient. $D$ ata are presented as the mean and standard error of the mean (SE ). Probability values and power statistics are given with statistic values and degrees of freedom.

\section{R ESULTS}

\section{Subject characteristics}

$M$ ean age, weight, height and percentage body fat were not significantly different between the restrained and unrestrained eating subjects (Table 1). Scores on the psychometric questionnaires were significantly higher for the restrained eating subjects ( $H-P$ score: $F=35.62, p<0.0001 ; F_{1}$ score: $F=21.77, p<0.001$ ) compared with the unrestrained eating subjects. 
TABLE 2

$M$ ean respiratory quotient ( 24-h $R Q$ ), energy intake ( $E I)$, energy expenditure (24-h $E E)$ and energy balance (EI-24-hEE) for all subjects on the three diets $(n=12)$. The absolute and relative contributions of the components sleeping metabolic rate (SM R), diet induced thermogenesis (DIT) and energy expenditure due to physical activity (ACT) are also presented $(n=11)$

\begin{tabular}{|c|c|c|c|c|c|c|}
\hline & \multicolumn{2}{|c|}{ Low-fat } & \multicolumn{2}{|c|}{ M ixed } & \multicolumn{2}{|c|}{ High-fat } \\
\hline & M ean & SE & M ean & SE & M ean & SE \\
\hline $\begin{array}{l}\text { 24-h R Q* } \\
\text { EI day } 1 \text { and } 2(\mathrm{M} \mathrm{J} / \mathrm{d}) \\
\text { EI day } 3(\mathrm{M} \mathrm{J} / \mathrm{d}) \\
24-h \mathrm{EE}(\mathrm{M} \mathrm{J} / \mathrm{d}) \dagger \\
\text { EI-24-h EE }(\mathrm{M} \mathrm{J} / \mathrm{d})\end{array}$ & $\begin{array}{r}0.90 \\
11 \cdot 76 \\
8 \cdot 60 \\
8 \cdot 70 \\
-0.10\end{array}$ & $\begin{array}{l}0.01 \\
0.08 \\
0.08 \\
0.18 \\
0.17\end{array}$ & $\begin{array}{r}0.86 \\
11 \cdot 78 \\
8.51 \\
8.44 \\
+0.07\end{array}$ & $\begin{array}{l}0.00 \\
0.09 \\
0.09 \\
0.14 \\
0.15\end{array}$ & $\begin{array}{r}0.82 \\
11 \cdot 80 \\
8.61 \\
8.47 \\
+0.14\end{array}$ & $\begin{array}{l}0.00 \\
0.10 \\
0.09 \\
0.16 \\
0.15\end{array}$ \\
\hline $\begin{array}{l}\operatorname{SMR}(M J / d) \\
\operatorname{DIT}(M J / d) \ddagger \\
\operatorname{ACT}(M J / d)\end{array}$ & $\begin{array}{l}6 \cdot 18 \\
1.23 \\
1 \cdot 28\end{array}$ & $\begin{array}{l}0.14 \\
0.07 \\
0 \cdot 12\end{array}$ & $\begin{array}{l}6 \cdot 13 \\
1 \cdot 10 \\
1 \cdot 20\end{array}$ & $\begin{array}{l}0 \cdot 14 \\
0 \cdot 10 \\
0 \cdot 10\end{array}$ & $\begin{array}{l}6.02 \\
0.99 \\
1.45\end{array}$ & $\begin{array}{l}0.12 \\
0.09 \\
0.15\end{array}$ \\
\hline $\begin{array}{l}\text { SMR }(\% \text { of } 24-h \text { EE }) \\
\text { DIT }(\% \text { of } 24-h \text { EE) } \\
\text { ACT }(\% \text { of } 24-h E E)\end{array}$ & $\begin{array}{l}71 \cdot 2 \\
14 \cdot 2 \\
14 \cdot 6\end{array}$ & $\begin{array}{l}0.9 \\
0.8 \\
1.2\end{array}$ & $\begin{array}{l}72 \cdot 8 \\
13 \cdot 0 \\
14 \cdot 2\end{array}$ & $\begin{array}{l}1 \cdot 3 \\
1 \cdot 1 \\
1 \cdot 1\end{array}$ & $\begin{array}{l}71 \cdot 3 \\
11 \cdot 8 \\
16 \cdot 9\end{array}$ & $\begin{array}{l}1 \cdot 4 \\
1 \cdot 1 \\
1 \cdot 6\end{array}$ \\
\hline
\end{tabular}

*Low-fat vs. mixed: $F(1,11)=65.65, p<0.0001$; low-fat vs. high-fat: $F(1,11)=249 \cdot 62, p<0.0001$; mixed vs. high-fat: $F(1,11)=117.48, p<0.0001$.

†L ow-fat vs. mixed: $F(1,11)=6 \cdot 64, p<0 \cdot 05$.

$\ddagger$ L ow-fat vs. high-fat: $F(1,10)=4.58, p=0.058$ (N S).

\section{Energy metabolism}

Over the 3-day intervals, provided energy intake was based on the calculated BM R of individual subjects. They were instructed to consume all food items and returned any left overs. There was a highly significant effect of diet composition on 24-h R Q; repeated measures A N OVA, F $(2,22)=144 \cdot 41, p<0 \cdot 0001$ (Table 2). Twentyfour-hour $E E$ was not significantly different between subjects on the $L F, M$ or $H F$ diet, although there was a trend towards a decreased 24-h EE on the $M$ and $\mathrm{HF}$ diets; $F(2,22)=3 \cdot 40, p=0.052$. Comparing the results of the LF and $M$ diet, 24-h $E E$ was significantly decreased on the $M$ diet.

Within individuals, energy expenditure and physical activity were related significantly, except for subject 4 on the LF and HF diet (Table 3). Therefore, data on SM R, DIT and ACT of 11 subjects are presented (Table 2). SM R, DIT and ACT were not significantly affected by diet composition, not expressed in $\mathrm{MJ} / \mathrm{d}$ nor expressed as a percentage of 24-h EE. The contribution of DIT to energy metabolism was highest on the LF diet and lowest on the HF diet, but differences were not statistically significant.

R estrained or unrestrained attitude towards eating

Twenty-four-hour RQ and 24-h EE were not significantly different between restrained and unrestrained eating subjects on the $L F, M$ and $H F$ diet; two-factor repeated measures A N OVA, 24-h RQ: $F(2,20)=0.51, p=0.61 ; 24-h$ EE: $F(2,20)=$ 


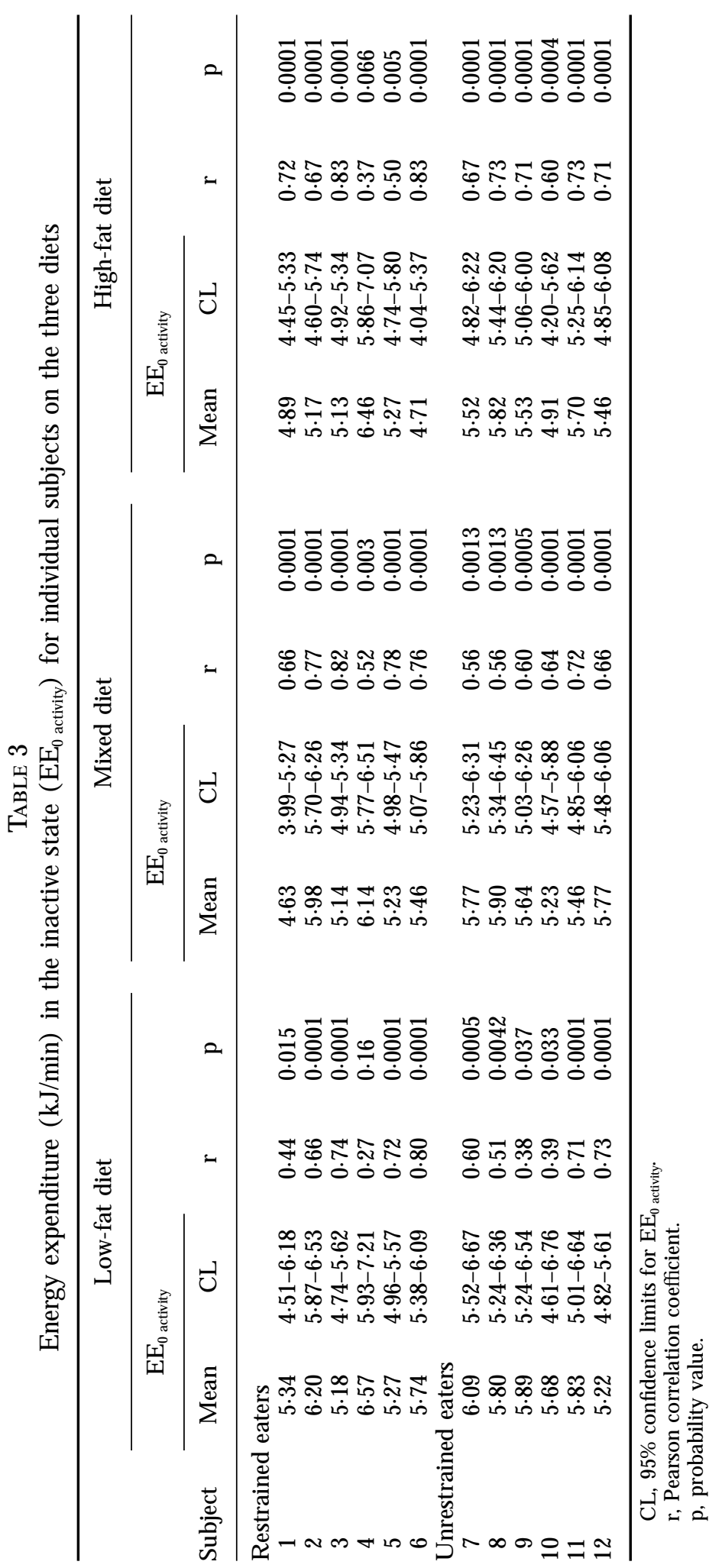


TABLE 4

$M$ ean respiratory quotient ( $24-h R Q$ ), energy expenditure ( 24-hEE) , sleeping metabolic rate (SM R), diet induced thermogenesis ( DIT) and energy expenditure due to physical activity $(A C T)$ for restrained and unrestrained eaters on the three diets

\begin{tabular}{|c|c|c|c|c|c|c|}
\hline & \multicolumn{2}{|c|}{ Low-fat } & \multicolumn{2}{|c|}{ M ixed } & \multicolumn{2}{|c|}{ High-fat } \\
\hline & M ean & SE & M ean & SE & M ean & SE \\
\hline $\begin{array}{l}\text { Restrained eaters } \\
24-h \text { R Q } \\
24-h \text { EE }(M J / d) \dagger \\
\text { SM R }(\% \text { of } 24-h E E) \\
\text { DIT }(\% \text { of } 24-h \text { EE) } \\
\text { ACT }(\% \text { of } 24-h E E)\end{array}$ & $\begin{array}{l}0.91 \\
8.58 \\
71 \cdot 8 \\
13 \cdot 7 \\
14.4\end{array}$ & $\begin{array}{l}0.00 \\
0.21 \\
0.8 \\
0.7 \\
1.5\end{array}$ & $\begin{array}{l}0 \cdot 86 \\
8 \cdot 21 \\
75 \cdot 2 \\
11 \cdot 5 \\
13 \cdot 3\end{array}$ & $\begin{array}{l}0.01 \\
0.21 \\
1.7 \\
1.6 \\
1.6\end{array}$ & $\begin{array}{l}0 \cdot 83 \\
8 \cdot 22 \\
73 \cdot 3 \\
10 \cdot 2 \\
16 \cdot 5\end{array}$ & $\begin{array}{l}0.00 \\
0.25 \\
1.9 \\
2 \cdot 1 \\
3 \cdot 2\end{array}$ \\
\hline $\begin{array}{l}\text { U nrestrained eaters } \\
24-h \mathrm{R} \text { Q } \\
24-\mathrm{h} \mathrm{EE} \mathrm{(M} \mathrm{J/d)} \\
\text { SM R ( } \% \text { of } 24-\mathrm{h} \mathrm{EE}) \\
\text { DIT ( } \% \text { of } 24-h \mathrm{EE}) \\
\text { ACT }(\% \text { of } 24-\mathrm{h} \mathrm{EE})\end{array}$ & $\begin{array}{l}0.90 \\
8 \cdot 83 \\
70 \cdot 6 \\
14 \cdot 6 \\
14 \cdot 7\end{array}$ & $\begin{array}{l}0.01 \\
0.29 \\
1.5 \\
1.5 \\
1.8\end{array}$ & $\begin{array}{l}0.86 \\
8 \cdot 67 \\
70 \cdot 8 \\
14 \cdot 3 \\
14 \cdot 9\end{array}$ & $\begin{array}{l}0.00 \\
0 \cdot 13 \\
1 \cdot 4 \\
1 \cdot 5 \\
1.5\end{array}$ & $\begin{array}{l}0.82 \\
8 \cdot 72 \\
69 \cdot 5 \\
13 \cdot 2 \\
17 \cdot 3\end{array}$ & $\begin{array}{l}0.00 \\
0.14 \\
1.8 \\
1.0 \\
1.5\end{array}$ \\
\hline
\end{tabular}

*L ow-fat vs. mixed; $F(1,5)=40.99, p<0.01$; low-fat vs. high-fat; $F(1,5)=256 \cdot 70, p<0.0001$; mixed vs. high-fat; $p<0.01 ; F(1,5)=38.61, p<0.01$.

tL ow-fat vs. mixed; $F(1,5)=22.84$, $p<0.01$; low-fat vs. high-fat; $F(1,5)=6.24, p=0.055$ (N S).

$\ddagger$ L ow-fat vs. mixed; $F(1,5)=23.09, p<0.01$; low-fat vs. high-fat; $F(1,5)=78.09, p<0.001$; mixed vs. high-fat; $F(1,5)=122 \cdot 56, p<0.0001$

$0.67, p=0.52$; Table 4. On the H F diet, there was a tendency towards a higher 24$\mathrm{h} \mathrm{R} Q$ for restrained eating subjects compared with unrestrained eating subjects; $F=$ $4.52, p=0.06$. Considering the separate components of energy metabolism, SM R, DIT and ACT, no significant differences between restrained and unrestrained eating subjects were observed, not on the LF diet, nor on the M or HF diet.

Within the group of restrained eating subjects $24-h R Q$ was significantly different between the three diets, $F(2,10)=90 \cdot 13, p<0 \cdot 0001$. 24-h EE was significantly lower on the $M$ and $H F$ diet compared with the $L F$ diet; $F(2,10)=6 \cdot 45, p<0.05$. Comparing the results of one diet vs. another, 24-h EE on the $M$ diet was significantly lower, and on the HF diet tended to be lower than on the LF diet.

Within the group of unrestrained eating subjects $24-\mathrm{h} R \mathrm{Q}$ was significantly different between the three diets; $F(2,10)=57 \cdot 26, p<0.0001$. Diet composition had no significant effect on 24-h EE.

\section{Body weight}

R esults of eight subjects on the three diets are presented; data of subjects 1,7 , 8 and 9 were not complete with respect to body weight measurements. Body weight did not change significantly over the 2 days in free-living conditions ( $L F$ diet: $+0.3 \pm 0.2 \mathrm{~kg} ; \mathrm{M}$ diet: $+0.3 \pm 0.1 \mathrm{~kg} ; \mathrm{H} \mathrm{F}$ diet: $+0.2 \pm 0.2 \mathrm{~kg}$ ). D uring the subsequent day in the respiration chamber, body weight decreased significantly on the LF $(-0.5 \pm 0.1 \mathrm{~kg} ; F(1,7)=16.68, p<0.01), M(-0.5 \pm 0.1 \mathrm{~kg} ; F(1,7)=21.24, p<0.01)$ and H F diet $(-0.6 \pm 0.1 \mathrm{~kg} ; F(1,7)=26.47, p<0.01)$. Over the 3-day intervals, body weight 
changes were not significantly different from zero ( $L F$ diet: $-0.2 \pm 0.1 \mathrm{~kg}$; M diet: $-0.2 \pm 0.2 \mathrm{~kg} ; \mathrm{HF}$ diet: $-0.3 \pm 0.2 \mathrm{~kg}$ ). There were no significant differences in changes of body weight due to the composition of the diet.

\section{ISCUSSION}

Several studies examining the metabolic effects of isoenergetic exchange of fat and carbohydrate reported no significant change in 24-h EE due to the composition of the diet (Hurni et al., 1982: diets with 5 or $40 \%$ fat energy and 78 or $43 \%$ carbohydrate energy for 7 days each; A bbott et al., 1990: a diet with 20\% fat energy and $65 \%$ carbohydrate energy for 5-43 days, and a diet with $42 \%$ fat energy and $43 \%$ carbohydrate energy for 6-32 days; $\mathrm{H}$ ill et al., 1991: diets with 20,45 or $60 \%$ fat energy and 60, 35 or 20\% energy as carbohydrate for 3 and 7 days each). Others investigated the effect of a 24-h dietary change in lean, obese and post-obese subjects, using isoenergetic diets which varied in fat ( 3 or $40 \%$ as energy) and carbohydrate ( 82 or $45 \%$ as energy) content (L ean \& James, 1988). In post-obese subjects only, they observed a lower 24-h EE on a high-fat diet compared with a low-fat diet. The results of the present study showed no significant effect of diet composition on 24-h EE over all subjects $(n=12)$. H owever, there was a trend towards a decreased 24-h EE on the M and HF diet, and 24-h EE on the M diet was significantly lower than on the LF diet. R esults are not consistent for influence of diet composition on the separate components of energy metabolism. SM R was significantly decreased in normal-weight subjects on a mixed diet compared with a low-fat diet (Hurni et al., 1982), or was not affected at all (L ean \& J ames, 1988; A bbott et al., 1990; Hill et al., 1991). In the present study, no significant effect of diet composition on SM R was observed. The method used for determination of D IT was based on simultaneous measurements of both physical activity and energy expenditure of the subjects. One minor shortcoming of this approach is that it does not measure work intensity. In general, two types of activity can be identified while being in a restricted space: (1) locomotor activity within the chamber (e.g. strolling around), and (2) movement of limbs with little displacement of the body's center of gravity (e.g. fidgeting) (Schutz et al., 1982). A lthough these two types of activity do not have the same energy cost, they cannot be discriminated by the radar system because the latter gives equal importance to all movements no matter what its apparent intensity. Studies of Bouten et al. (1994, personal communication) indicated that physical activity measured by a radar system in a respiration chamber correlated significantly with physical activity measured by an advanced triaxial accelerometer, resulting in similar values for $E_{0 \text { activity }}$ and DIT. The contribution of DIT to energy metabolism was expected to be lower on a high-fat diet (Schwartz et al., 1985; Lean \& J ames, 1988). A ccording to A cheson et al. (1984a) the explanation for this finding could be the greater obligatory cost of glycogen storage and a facultative increase in thermogenesis due to glucogenic stimulation of the sympathetic nervous system (A cheson et al., 1984b). A bbott et al. (1990), however, found no change in DIT due to the composition of the diet. In the present study no effect of dietary fat and carbohydrate exchange on DIT was observed either, although the contribution of DIT to energy metabolism was highest on the LF diet and lowest on the HF diet (Table 2). Considering the energy expenditure for physical activity, no significant effect of diet composition 
could be observed, not in the present study, nor in other studies (A bbott et al., 1990; $H$ ill et al., 1991).

A second objective of this study was to examine whether the influence of diet composition was different for different types of subjects, to explain possible consequences of diet composition for developing obesity. Within the group of restrained eaters 24-h EE was significantly lower during the $M$ diet and tended to be lower during the HF diet, compared with the LF diet (Table 4). Therefore, the decreased 24-h EE on the M and HF diet as observed for all subjects $(n=12)$ was on account of the group of restrained eating subjects (Tables 2 and 4). Tuschl et al. (1990) conducted a study on the relationship between average daily metabolic rate and the eating behaviour of normal-weight women. Although the restrained eaters in their study had a higher body mass index compared with the unrestrained eaters, self-reported energy intake and measured energy expenditure were significantly lower. Because body weight did not change during the observation period, this should mean that restrained eaters have diminished energetic requirements, which in turn can induce chronic weight concern. On the other hand, restrained eaters report multiple dieting periods with various weight fluctuations, resulting in a decreased energy expenditure. In the present study, body mass index and the percentage of body fat were not significantly different between the groups of restrained and unrestrained eaters. $\mathrm{N}$ evertheless, the response of restrained and unrestrained eaters to dietary exchange of fat and carbohydrate differed substantially. R estrained eaters showed a decreased fat oxidation compared with unrestrained eaters in response to a high-fat low-carbohydrate diet, resulting in a positive fat balance for restrained eaters (Verboeket-van de Venne et al., 1994). This finding was also reflected in the observed tendency towards a higher 24-h RQ in restrained eaters on the HF diet. Therefore, a LF diet would be beneficial with respect to development and treatment of obesity, especially if subjects have a restrained type of eating behaviour.

One of the difficulties of a short-term study is in knowing whether it provides an indication of the long-term responses. F or example, major dietary changes require alterations in enzyme levels, the level of carrier proteins, and gene expression in order that a different nutrient or metabolite flux can be handled appropriately. The present study focussed on the short-term effects of dietary fat and carbohydrate exchange on energy metabolism of normal-weight subjects being more or less susceptible to developing obesity. L ongitudinal studies in a larger group of subjects will be necessary to examine whether the results found in the present study can be extended to the long-term, i.e. whether restrained eaters indeed beco me obese (sooner) in response to a diet with a higher fat content compared with unrestrained eaters.

In conclusion, short-term dietary exchange of fat and carbohydrate had no significant effect on 24-h EE, although there was a trend towards a decreased 24-h $\mathrm{EE}$ the $\mathrm{M}$ and $\mathrm{HF}$ diet. When the subjects' attitude towards eating was taken into account, 24-h EE was significantly lower for restrained eating subjects at the $M$ diet and tended to be lower at the HF diet compared with the LF diet, reflecting a possible risk factor at diets with a higher fat content in developing obesity.

\section{R EFERENCES}

A bbott, W. G. H., Howard, B. V., R uotolo, G.\& R avussin, E. (1990). Energy expenditure in humans: effects of dietary fat and carbohydrate. A merican J ournal of Physiology, 258, E 347-51. 
A cheson, K. J., Schutz, Y., Bessard, T., R avussin, E. \& J équier, E. (1984a). N utritional influences on lipogenesis and thermogenesis after a carbohydrate meal. A merican J ournal of Physiology, 246, E62-70.

A cheson, K. J., R avussin, E., Wahren, J. \& J équier, E. (1984b). Thermic effect of glucose in man: obligatory and facultative thermogenesis. J ournal of Clinical Investigation, 74, 1572-80.

Bouten, C. V. C., Westerterp, K. R., Verduin, M . \& J anssen, J. D. (1994). A ssessment of energy expenditure for physical activity using a triaxial accelerometer. $M$ edicine and Science in Sports and Exercise, 26, 1516-23.

D reon, D. M ., Frey-H ewitt, B., Ellsworth, N., Williams, P. T., Terry, R. B. \& Wood, P. D. (1988). D ietary fat:carbohydrate ratio and obesity in middle-aged men. A merican J ournal of Clinical N utrition, 47, 995-1000.

D uncan, K. H., Bacon, J. A. \& Weinsier, R. L. (1983). The effects of high and low energy density diets on satiety, energy intake and eating time of obese and nonobese subjects. A merican J ournal of Clinical N utrition, 37, 763-7.

F latt, J. P. (1985). Energetics of intermediary metabolism. In: G arrow, J. S. \& H alliday, E. (Eds). Substrate and energy metabolism in man. Pp. 58-69. London: Libbey.

Harris, J. A. \& Benedict, F. G. (1919). A biometric study of basal metabolism in man. Carnegie Institution of Washington, 190.

H autvast, J. G . A . J . (1975). Ontwik keling van een systeem om gegevens van voedingsenquetes met behulp van een computer te verwerken. Voeding, 36, 356-61.

Herman, C. P. \& Polivy, J. (1980). R estrained eating. In: Stunkard, A. (Ed.). O besity. Pp. 208-24. Philadel phia: W B Saunders.

H ill, J. O., Peters, J. C., R eed, G. W., Schlundt, D. G., Sharp, T. \& G reene, H. L. (1991). $N$ utrient balance in humans: Effects of diet composition. A merican J ournal of Clinical N utrition, 54, 10-7.

H urni, M., Burnand, B., Pittet, P. \& J équier, E. (1982). M etabolic effects of a mixed and a high-carbohydrate low-fat diet in man, measured over $24-\mathrm{h}$ in a respiration chamber. B ritish J ournal of N utrition, 47, 33-43.

L aessle, R. G ., Tuschl, R . J ., K otthaus, B. C. \& Pirke, K . M . (1989). Behavioral and biological correlations of dietary restraint in normal life. A ppetite, 12, 83-94.

L ean, M. E. J . \& J ames, W. P. T. (1988). M etabolic effects of isoenergetic nutrient exchange over 24 hours in relation to obesity in women. International J ournal of O besity, 12, 15-27.

Lissner, L., L evitsky, D. A., Strupp, B. J ., K alkwarf, H . J . \& R oe, D. A. (1987). D ietary fat and the regulation of energy intake in human subjects. A merican J ournal of Clinical N utrition, 46, 886-92.

M cN eill, G., Bruce, A. C., R alph, A.\& James, W. P. T. (1988). Inter-individual differences in fasting nutrient oxidation and the influence of diet composition. International J ournal of 0 besity, $12,455-63$.

N air, K. S., H alliday, D.\& Garrow, J. S. (1983). Thermic response to isoenergetic protein, carbohydrate or fat meals in lean and obese subjects. Clinical Science, 65, 307-12.

R avussin, E., Lillioja, S., K nowler, W. C., Christin, L., Freymond, D., A bbott, W. G. H., Boyce, V., H oward, B. V. \& Bogardus, C. (1988). R educed rate of energy expenditure as a risk factor for body-weight gain. $\mathrm{N}$ ew England J ournal of M edicine, 318, 467-72.

Romieu, I., Willett, W. C., Stampfer, M. J., Colditz, G. A., Sampson, L., R osner, B., Hennekens, C. H. \& Speizer, F. E. (1988). Energy intake and other determinants of relative weight. A merican J ournal of Clinical N utrition, 47, 406-12.

Schoffelen, P. F. M., Saris, W. H. M., Westerterp, K. R. \& ten H oor, F. (1984). Evaluation of an automatic indirect calorimeter for measurement of energy balance in man. In: van Es, A.J.H. (Ed.). H uman energy metabolism: physical activity and energy expenditure measurements in epidemiological research based upon direct and indirect calorimetry. Euro $\mathrm{N}$ ut R eport N o. 5, Pp. 51-4. Wageningen: The $\mathrm{N}$ etherlands $\mathrm{N}$ utrition $\mathrm{F}$ oundation.

Schutz, Y., Bessard, T. \& J équier, E. (1984). D iet-induced thermogenesis measured over a whole day in obese and nonobese women. American J ournal of Clinical Nutrition, 40, 542-52.

Schutz, Y., R avussin, E., D iethelm, R . \& J équier, E. (1982). Spontaneous physical activity measured by radar in obese and control subjects studied in a respiration chamber. International J ournal of O besity, 6, 23-8. 
Schwartz, R. S., R avussin, E., M assari, M ., O'Connell, M . \& R obbins, D. C. (1985). The thermic effect of carbohydrate versus fat feeding in man. M etabolism, 34, 285-93.

Siri, W. E. (1956). The gross composition of the body. Advances in Biological and M edical Physiology, 4, 239-80.

Stunkard, A . J. \& M essick, S. (1985). The three factor eating questionnaire to measure dietary restraint, disinhibition and hunger. J ournal of Psychological Research, 29, 71-83.

Swaminathan, R., K ing, R. F. J., Holmfield, J. \& Wales, J. K. (1981). D ietary fat induced thermogenesis in obesity. Clinical Science, $62,16 \mathrm{P}$.

Tremblay, A ., Plourde, G ., D espres, J. P. \& B ouchard, C . (1989). I mpact of dietary fat content and fat oxidation on energy intake in humans. A merican J ournal of Clinical N utrition, 49, 799-805.

Tuschl, R. J ., Platte, P., Laessle, R. G ., Stichler, W. \& Pirke, K. M . (1990). E nergy expenditure and everyday eating behavior in healthy young women. A merican J ournal of Clinical N utrition, 52, 81-6.

Verboeket-van de Venne, W. P. H. G. \& Westerterp, K. R. (1991). Influence of the feeding frequency on nutrient utilization in man: Consequences for energy metabolism. E uropean J ournal of Clinical Nutrition, 45, 161-9.

Verboeket-van de Venne, W. P. H. G., Westerterp, K. R. \& K ester, A. D. M . (1993). Effect of the pattern of food intake on human energy metabolism. B ritish J ournal of N utrition, $70,103-15$.

Verboek et-van de Venne, W. P. H. G., Westerterp, K. R. \& Ten H oor, F. (1994). Substrate utilization in man: Effects of dietary fat and carbohydrate. M etabolism, 42, 152-6.

Weir, J. B. de V. (1949). N ew methods for calculating metabolic rate with special reference to predict protein metabolism. J ournal of P hysiology, 109, 1-9.

Westerterp-Plantenga, M. S., van den Heuvel, E., Wouters, L. \& ten Hoor, F. (1990a). D eceleration in cumulative food intake curves, changes in body temperature, and dietinduced thermogenesis. Physiology and B ehavior, 48, 831-6.

Westerterp-Plantenga, M. S., Westerterp, K.R., N icolson, N. A., M ordant, A., Schoffelen, P. F. M. \& ten Hoor, F. (1990b). The shape of the cumulative food intake curve in humans, during basic and manipulated meals. P hysiology and B ehavior, 47, 569-76.

Westerterp-Plantenga, M . S., van den H euvel, E., Wouters, L . \& ten H oor, F. (1991). R estrained eating, obesity and cumulative food intake curves during four-course meals. A ppetite, 16 , 149-58.

Zed, C. \& James, W. P. T. (1986). D ietary thermogenesis in obesity: fat feeding at different energy intakes. International J ournal of O besity, 10, 375-90.

\section{A PPENDIX}

Food items of the low-fat, mixed, and high-fat diet, as consumed during the respiration chamber measurements.

Low-fat diet (8.5 MJ)

Breakfast

orange juice

$200 \mathrm{ml}$

low-fat crackers

$6 \times 4 \mathrm{~g}$

cheese spread $(20+)$

$15 \mathrm{~g}$

jam

$3 \times 15 \mathrm{~g}$

meat-products $(<10 \mathrm{~g}$ fat per $100 \mathrm{~g}) \quad 2 \times 15 \mathrm{~g}$

Lunch

low-fat curd with fruits

$90 \mathrm{~g}$

low-fat crackers

$6 \times 4 \mathrm{~g}$

cheese spread $(20+)$

$3 \times 15 \mathrm{~g}$

jam

$3 \times 15 g$

apple, medium

$120 \mathrm{~g}$

Dinner

apple juice

$200 \mathrm{ml}$

mix for preparing goulash $\quad 13.8 \mathrm{~g}$ 


\section{water}

steak tartare, unprepared

$75 \mathrm{~g}$

spaghetti, uncooked

$87.5 \mathrm{~g}$

leek, raw

$37.5 \mathrm{~g}$

onions, raw

$37.5 \mathrm{~g}$

peaches on syrup

$125 \mathrm{~g}$

red paprika, raw

$75 \mathrm{~g}$

tomato-puree

$17.5 \mathrm{~g}$

yoghurt with fruits

$125 \mathrm{~g}$

Evening snack

orange juice

$125 \mathrm{~g}$

cookies

$2 \times 15 \mathrm{~g}$

M ixed diet (8.4 M J)

Breakfast

wholemeal bread

$3 \times 35 \mathrm{~g}$

low-fat table margarine

jam

$3 \times 5 \mathrm{~g}$

meat-products ( $<10 \mathrm{~g}$ fat per $100 \mathrm{~g}$ )

$15 \mathrm{~g}$

$15 \mathrm{~g}$

meat-products (20-30 g far per $100 \mathrm{~g}$ )

$15 \mathrm{~g}$

L unch

semi-skim milk

$150 \mathrm{ml}$

whole-meal bread

$3 \times 35 \mathrm{~g}$

low-fat table margarine

$3 \times 5 \mathrm{~g}$

Gouda cheese, $48+$

$20 \mathrm{~g}$

jam

$2 \times 15 \mathrm{~g}$

Dinner

mix for preparing goulash

$13.8 \mathrm{~g}$

minced meat ( $50 \%$ beef, $50 \%$ pork),

unprepared

$80 \mathrm{~g}$

spaghetti, uncooked

$87.5 \mathrm{~g}$

leek, raw

$37.5 \mathrm{~g}$

onions, raw

$37.5 \mathrm{~g}$

peaches on syrup

$20 \mathrm{~g}$

red paprika, raw

yoghurt with fruits

$62.5 \mathrm{~g}$

$150 \mathrm{~g}$

Evening snack

orange juice

$200 \mathrm{ml}$

cookies

$2 \times 10 \mathrm{~g}$

$\mathrm{H}$ igh-fat diet (8.5 M J) Breakfast

wholemeal bread

$35 \mathrm{~g}$

rye-bread

$2 \times 25 \mathrm{~g}$

low-fat table margarine

$3 \times 5 \mathrm{~g}$

G ouda cheese, $48+$

$20 \mathrm{~g}$

meat-products (20-30 g fat per $100 \mathrm{~g}$ )

$2 \times 15 \mathrm{~g}$

semi-skim milk

$100 \mathrm{ml}$

whole-meal bread

$2 \times 35 \mathrm{~g}$

rye-bread

$25 \mathrm{~g}$

low-fat table margarine

$3 \times 5 \mathrm{~g}$

G ouda cheese, $48+$

$20 \mathrm{~g}$

$2 \times 15 \mathrm{~g}$ 
Dinner

minced meat ( $50 \%$ beef, $50 \%$ pork),

unprepared

$75 \mathrm{~g}$

spaghetti, uncooked

$87.5 \mathrm{~g}$

G ouda cheese, $48+$

$30 \mathrm{~g}$

kitchen margarine

$10 \mathrm{~g}$

leek, raw

$37.5 \mathrm{~g}$

onions, raw

$37.5 \mathrm{~g}$

red paprika, raw

tomato-puree

$17.5 \mathrm{~g}$

whipped cream

$12.5 \mathrm{ml}$

Evening snack

cake

$2 \times 20 \mathrm{~g}$

$\mathrm{N}$ ote that these diets were consumed by all subjects, except subject 7 who received diets with an energy content of approximately $9.5 \mathrm{M} \mathrm{J}$. 